\title{
Prosopis pods as human food, with special reference to Kenya ${ }^{\#}$
}

\author{
SK Choge ${ }^{1}$, NM Pasiecznik², M Harvey ${ }^{3}$, J Wright ${ }^{3}$, SZ Awan ${ }^{3}$ and PJC Harris ${ }^{4 *}$ \\ ${ }^{1}$ Kenya Forestry Research Institute, P.O. Box 20412, 00200 Nairobi, Kenya \\ ${ }^{2}$ Agroforestry Enterprises, Villebeuf, 71550 Cussy-en-Morvan, France \\ ${ }^{3}$ Henry Doubleday Research Association, Ryton Organic Gardens, Coventry CV8 3LG, UK \\ ${ }^{4}$ Department of Geography, Environment and Disaster Management, Coventry University, Priory Street, Coventry CV1 5FB, UK
}

\begin{abstract}
Several legume tree and shrub species of the genus Prosopis from South and Central America have been distributed around the dry regions of the world over the past 200 years. The first documented introduction of Prosopis in Kenya was in 1973, since when it has spread widely, adversely affecting natural habitats, rangelands and cultivated areas. $P$. juliflora is the most common naturalised species in Kenya, but $P$. pallida also occurs. In contrast to their undesirable effects as invasive weeds, many Prosopis species are valuable multipurpose resources in their native range, providing timber, firewood, livestock feed, human food, shade, shelter and soil improvement. The pods, which are high in sugars, carbohydrates and protein, have been a historic source of food for human populations in North and South America providing flour and other edible products. However, this indigenous knowledge has not followed the Prosopis trees and the fruit are unused or provide only fodder for livestock in most of Africa and Asia. Although Prosopis will not easily be eradicated in Kenya, a degree of control may be achieved through intensive utilisation of tree products and by improved management. In 2005, a project was launched in Kenya to develop income-generating activities using Prosopis. A workshop in 2006 explored the possibility of producing locally-acceptable food from Prosopis flour. Taste tests and feedback on the different recipes indicated that all of the food made with $20 \%$ Prosopis flour had a pleasant taste. Preliminary analyses of Prosopis flour samples from Kenya indicate good nutritional properties, but also the presence of aflatoxins and Ochratoxin A. Further study is required to determine toxin levels in freshly harvested pods, and in pods and flour after various periods of storage, and to develop appropriate harvesting and storage methods to maximise nutritional benefit and minimise risk to human health.
\end{abstract}

Keywords: Aflatoxin, human food, Kenya, Ochratoxin A, Prosopis

\section{Introduction}

The genus Prosopis in the family Leguminosae (Fabaceae), subfamily Mimosoideae is native to the Americas, Africa and Asia, and comprises 44 species (Burkart, 1976). Prosopis species are generally fast-growing, drought-resistant, nitrogenfixing trees or shrubs adapted to poor and saline soils in arid and semi-arid zones. Several species from South and Central America, especially the sub-tropical $P$. chilensis, $P$. glandulosa and $P$. velutina, and the tropical $P$. juliflora and $P$. pallida, have been distributed around the world over the last 200 years and are now widespread in dry parts of Sahelian and East Africa, South Africa, Pakistan, India, Brazil and Australia (Pasiecznik et al., 2001).

The earliest known introductions of Prosopis to Africa were to Senegal (1822), South Africa (1880) and Egypt (1900) (Zimmerman, 1991; Pasiecznik et al., 2001). In Kenya, the first documented introduction of Prosopis, from Brazil and Hawaii, was in 1973 for rehabilitation of quarries near Mombassa (Johansson, 1990). During the 1970s and early 1980s, there were uncoordinated introductions of Prosopis to many parts of Kenya by NGOs and government departments with seed sourced from

\footnotetext{
Revised version. Originally presented at the International Symposium on the Nutritional Value and Water Use of Indigenous Crops for Improved Livelihoods held on 19 and 20 September 2006 at the University of Pretoria in Pretoria, South Africa

* To whom all correspondence should be addressed.

푱 +44 247688 8483; fax: +44 247688 8400; e-mail: p.harris@coventry.ac.uk
}

commercial suppliers without reference to origin or quality (Johansson, 1990; Otsamo and Maua, 1993). Over the years, Prosopis has spread outside the designated plantation areas, adversely affecting natural habitats, rangelands and cultivated areas in many parts of the country (Choge et al., 2002). P. juliflora is the most common naturalised species but $P$. pallida has also been confirmed by the present authors. Prosopis has been declared a noxious weed in Kenya, with legal disputes over compensation for its spread and subsequent loss of livelihoods, especially in pastoral regions.

In contrast to their undesirable effects as invasive weeds, many Prosopis species are valuable multipurpose resources in their native range, providing timber, firewood, livestock feed, human food, shade, shelter and soil improvement (Pasiecznik et al., 2001). This paper reviews the extensive scientific literature on the uses of Prosopis as human food. Also presented are the results of a project launched in Kenya to develop incomegenerating activities using Prosopis. Analysis of Prosopis pod flour from Kenya was undertaken to assess the food quality and safety of locally prepared material. A workshop in Kenya in 2006 explored the possibility of producing locally acceptable food from Prosopis flour.

\section{Prosopis as human food}

Pod yields as high as $100 \mathrm{~kg} \cdot \mathrm{yr}^{-1}$, and often 20 to $50 \mathrm{~kg} \cdot \mathrm{yr}^{-1}$ have been recorded for single trees. If cultivated as an orchard crop, production is highly variable, normally ranging from 1 to $8 \mathrm{t} \cdot \mathrm{ha}^{-1} \cdot \mathrm{yr}^{-1}$, but Prosopis can yield up to $10 \mathrm{t} \cdot \mathrm{ha}^{-1}$ of fruit (Felker, 1979). The pods have been an historic source of food for human populations, for example in the Sonoran Desert in North Amer- 
ica, where Indian tribes made flour and dough with the dried or toasted pulp from ripe pods (Simpson, 1977). In Northern Argentina, flour made from the pulp of Prosopis is known as 'patay' and is still consumed today (Ochoa, 1996). In Peru, $P$. pallida pods are ground into flour to make bread, cakes or a rich porridge. Traditionally, dried pods were pounded in a pestle and mortar to produce a coarse flour, or ground using a variety of stone mills (Felger, 1977). Other methods of manual or mechanical grinding have also proved successful for processing Prosopis pods (Meyer et al., 1982; Saunders et al., 1986; Del Valle et al., 1987; Grados and Cruz, 1996). The absence of starch is a limitation to Prosopis flour levels in bread formulations. Mixing 5-25\% Prosopis flour with wheat flour produces products which have acceptable taste. Sweet bread containing $5 \%$ P. pallida flour is acceptable in texture and taste, though up to $25 \%$ has been used in making biscuits, which also reduces the amount of additional sugar required (Cruz, 1999).

Flour is the main product considered in this paper, but Prosopis pods also yield an impressive range of other food products. In Peru, pods of $P$. pallida are boiled into syrup called 'algarrobina'. Another food product from Prosopis is 'yupisín', a beverage which is obtained by water extraction of the sugars from the pod. A fermented beverage, 'aloja' can be produced and is used as a substitute for beer or wine (Cruz, 1986; Ochoa, 1996). In Brazil, the production of a protein isolate (Baião et al., 1987) and a protein-enriched flour (Ruiz, 1997) from $P$. juliflora seeds and its application in bread-making have been reported. $P$. pallida pulp flour can also be used as an ingredient in many other food preparations, such as cakes, ice creams and other desserts. P. pallida pulp flour has been converted into an instantly soluble powder, and could be used as a cocoa pow- der substitute. Coffee substitute has been made from $P$. juliflora in Brazil (Azevedo Rocha, 1987).

\section{Nutritional qualities}

The fruit produced by Prosopis is high in sugars, carbohydrates and protein. Pods from species of section Algarobia of the genus, which includes the common weedy species in Africa, contain 7 to $22 \%$ protein, 30 to $75 \%$ carbohydrates, 11 to $35 \%$ crude fibre, 1 to $6 \%$ fat and 3 to $6 \%$ ash (e.g. Oduol et al., 1986; Galera et al., 1992; Anttila et al., 1993). Care should be taken in interpreting food value data for Prosopis from the literature as these may be given for whole pods, or for only the pulp (mesocarp) or seed fractions. Table 1 shows the proximate analyses of whole pods of $P$. juliflora and $P$. pallida, the two species introduced into Kenya.

Further analyses of $P$. pallida fruit, but for pulp only, are shown in Tables 2, 3 and 4. The main soluble component of the pulp of $P$. pallida is sucrose (46\%), representing over $90 \%$ of total soluble sugars, while the reducing sugars, glucose, fructose and xylose, are present in very small amounts (Cruz et al., 1987; Sáenz et al., 1987). Talpada (1985) found that the sugar content of $P$. juliflora pods varied from 13 to $20 \%$ in different seasons and years, showing a strong environmental effect on pod composition. Soluble sugars from the pericarp of $P$. juliflora from Ecuador comprise $75 \%$ sucrose, $12 \%$ fructose, $5 \%$ glucose, $5 \%$ inositol and $1 \%$ raffinose (Marangoni and Alli, 1988).

Dietary fibre represents $30 \%$ of the pulp and is largely insoluble. More than half of the fibre fraction consists of neutral polysaccharides (Bravo et al., 1994). High iron levels have been reported in $P$. juliflora from Ecuador and Brazil (Figueiredo,

\begin{tabular}{|l|c|c|c|c|c|c|c|c|}
\hline \multicolumn{9}{|c|}{ PABLE 1 } \\
\hline Species & Location & Dry matter & $\begin{array}{c}\text { Crude } \\
\text { protein }\end{array}$ & Crude fibre & $\begin{array}{c}\text { Ether } \\
\text { extract }\end{array}$ & Ash & $\begin{array}{c}\text { Nitrogen } \\
\text { free extract }\end{array}$ & Source \\
\hline PP & Peru & 85.9 & 9.1 & 18.4 & 1.0 & 3.9 & 65.3 & $\mathrm{a}$ \\
\hline PJ & Peru & 82.0 & 9.1 & 13.6 & 0.4 & 5.8 & 71.1 & $\mathrm{a}$ \\
\hline PP & Brazil & - & 8.1 & 22.1 & 1.3 & 5.0 & 64.0 & $\mathrm{~b}$ \\
\hline PJ & Brazil & 87.4 & 7.1 & 12.3 & 1.1 & 3.3 & 63.6 & $\mathrm{C}$ \\
\hline PJ & India & 88.5 & 12.3 & 28.0 & 1.3 & 1.4 & 46.3 & $\mathrm{~d}$ \\
\hline PJ & Mexico & 90.1 & 16.2 & 23.4 & 3.5 & 6.0 & 50.9 & $\mathrm{a}$ \\
\hline PJ & Niger & 92.6 & 12.9 & 18.0 & 4.0 & 4.5 & 58.9 & $\mathrm{e}$ \\
\hline PJ & Kenya & - & 16.0 & 22.0 & 3.4 & 4.5 & 54.1 & $\mathrm{f}$ \\
\hline PJ & S. Africa & - & 13.9 & 27.7 & 3.0 & 4.8 & 50.6 & $\mathrm{~g}$ \\
\hline
\end{tabular}

From: a - Díaz Celis (1995); b - Lima (1994); c - Galera et al. (1992); d-Anon. (1943); e - Touzeau (1973); $f$ - Anttila et al. (1993); $g$ - Gohl (1981).

\begin{tabular}{|l|c|}
\hline \multicolumn{2}{|c|}{ TABLE $\mathbf{2}$} \\
Composition of $\boldsymbol{P}$. pallida pulp \\
\hline Component & (g/100 g dry matter) \\
\hline Total soluble sugars & 48.5 \\
\hline Total dietary fibre & 32.2 \\
\hline Protein (N x 6.25) & 8.1 \\
\hline Fat & 0.8 \\
\hline Ash & 3.6 \\
\hline
\end{tabular}

Adapted from: Cruz et al. (1987); Cruz (1990); Saura et al. (1991); Salazar (1993); Bravo et al. (1994); Grados and Cruz (1996).
TABLE 3

Mineral and vitamin composition of pulp from $P$. pallida pods

\begin{tabular}{|l|c|l|c|}
\hline Minerals & $\begin{array}{c}\text { (g/kg dry } \\
\text { matter) }\end{array}$ & Vitamins & $\begin{array}{c}\text { (mg/kg } \\
\text { sample) }\end{array}$ \\
\hline Potassium & 26.5 & Vitamin A & not detected \\
\hline Sodium & 1.1 & Vitamin E & 5 \\
\hline Calcium & 0.8 & Vitamin B1 & 1.9 \\
\hline Magnesium & 0.9 & Vitamin B2 & 0.6 \\
\hline Copper & Trace & Vitamin B6 & 2.35 \\
\hline Zinc & Trace & Nicotinic acid & 31 \\
\hline Manganese & Trace & Vitamin C & 60 \\
\hline Iron & 0.3 & Folic acid & 0.18 \\
\hline & & Calcium pantothenate & 10.5 \\
\hline
\end{tabular}

From: Cruz et al. (1987). 


\begin{tabular}{|l|c|l|c|}
\hline \multicolumn{4}{|c|}{ TABLE 4 } \\
Amino acid composition of $\boldsymbol{P}$. pallida pulp \\
\hline Amino acid & $\begin{array}{c}\text { (g/100 g dry } \\
\text { matter) }\end{array}$ & Amino acid & $\begin{array}{c}\text { (g/100 g dry } \\
\text { matter) }\end{array}$ \\
\hline Aspartic acid & 8.51 & Isoleucine & 3.26 \\
\hline Throenine & 4.68 & Leucine & 7.94 \\
\hline Serine & 4.96 & Tyrosine & 2.84 \\
\hline Glutamic acid & 10.07 & Phenylalanine & 2.98 \\
\hline Proline & 23.40 & Lysine & 4.26 \\
\hline Glycine & 4.68 & Histidine & 1.99 \\
\hline Alanine & 4.26 & Arginine & 4.82 \\
\hline Cysteine & 0.43 & Tryptophan & 0.89 \\
\hline Methionine & 0.57 & Hydroxyproline & 2.13 \\
\hline Valine & 7.80 & & \\
\hline
\end{tabular}

From: Cruz et al. (1987).

1975; Marangoni and Alli, 1988) but no figures for its bio-availability are given. The vitamins $\mathrm{C}, \mathrm{B} 6$ and calcium pantothenate are present in significant amounts in pulp from $P$. pallida pods (Grados and Cruz, 1996).

Nearly all the essential amino acids are present in amounts which fulfil the requirements of the FAO/WHO 'standard protein', thus indicating an acceptable nutritional quality of the protein. Methionine and cysteine are the limiting amino acids. The fat content of pulp is low (Table 2), but is reported to be $7 \%$ in $P$. pallida seed cotyledons (Jiménez and Vergara 1977) with the major fatty acids found in extracted oil being linoleic acid (39\%), oleic acid (29\%), palmitic acid (13\%) and stearic acid (10\%). Similar values have been reported for P. juliflora (Marangoni and Alli, 1988). Table 5 shows the composition of flour from whole $P$. juliflora pods produced in the course of the present study. This confirms the product as a high protein, high sugar material of considerable human food value.

\section{Food safety}

Consumption of Prosopis products by humans, even as a staple food, has not resulted in any recorded harmful effects on health (Pasiecznik et al., 2001). Both Pak et al. (1977) with P. tamarugo and Becker and Grosjean (1980) with P. glandulosa and $P$. velutina failed to detect cyanogenic glycosides, but the latter authors did find phytohaemaglutinins in the seeds which meant they had to be heated (cooked) to eliminate this. Significantly smaller amounts of polyphenols and tannins were found in pods of $P$. pallida fruit than in carob (Ceratonia siliqua) pods (Salazar 1993; Bravo et al., 1994). Prosopis pods and seeds have been reported to be almost totally devoid of trypsin inhibitor activity (<6 TIU/mg) (Zolfaghari and Harden, 1982; Ortega-Nieblas et al., 1996), although a trypsin inhibitor from $P$. juliflora seeds has been characterised (Monte-Negreiros et al., 1991). Hexanal, which is an indicator of rancidity from oxidation of fats, was found in whole ground Prosopis seeds while mesocarp flour was devoid of this compound (Felker, pers. comm.). Prosopis flour from Argentina has been found to be free of aflatoxins (Felker, pers. comm.). In contrast, pods of Prosopis spp. in the wild in the Sonoran Desert in Arizona, USA, have been reported to have high levels of aflatoxin and to be important reservoirs of aflatoxin-producing fungi (Boyd and Cotty, 2001). Insect damaged pods had significantly higher aflatoxin than intact pods.

\section{From weed to resource}

Although food products made from Prosopis flour are consumed

\begin{tabular}{|l|c|}
\hline \multicolumn{2}{|c|}{ TABLE 5 } \\
$\begin{array}{c}\text { Composition of flour from whole pods of } \\
\text { P. juliflora from Baringo District, Kenya }\end{array}$ \\
\hline Component & $\begin{array}{c}\text { (value/100 g } \\
\text { dry matter) }\end{array}$ \\
\hline Protein (g) & 16.2 \\
\hline Total sugars (g) & 13.0 \\
\hline Fructose (g) & 3.2 \\
\hline Glucose (g) & 0.8 \\
\hline Galactose (g) & 0.8 \\
\hline Sucrose (g) & 7.5 \\
\hline Maltose (g) & $<0.4$ \\
\hline Lactose (g) & 0.7 \\
\hline Carbohydrate (g) & 69.2 \\
\hline Energy value (kJ) & 1530 \\
\hline Dietary fibre (g) & 47.8 \\
\hline Fat (g) & 2.12 \\
\hline Monosaturated fatty acids (g) & 0.4 \\
\hline Polyunsaturated fatty acids (g) & 1.06 \\
\hline Saturated fatty acids (g) & 0.56 \\
\hline Sodium (mg) & 20 \\
\hline Ash (g) & 6.0 \\
\hline Total solids (g) & 93.5 \\
\hline
\end{tabular}

in the native range in South and Central America, this indigenous knowledge has not followed Prosopis trees across the Atlantic, where the fruits are unused or provide only fodder for livestock. Pasiecznik (2002) argues that in Central and South America, many rural economies rely heavily on native Prosopis to supply a trade in processed products, while this is not the case where it was introduced. Thus, one reason why it often becomes an invasive weed, is because the full range of its uses and management is not known.

Although Prosopis will not easily be eradicated in Kenya, a degree of control may be achieved through intensive utilisation of tree products and by improved management. Trading of its products, converting a weed into a valuable resource, presents an opportunity for socio-economic benefits to the communities living in marginal areas of the country where extensive areas of Prosopis are found. Furthermore, invasive Prosopis is now common in many of the parts of Sahelian and eastern Africa, including Kenya and Niger where large populations face malnutrition due to drought, a situation exacerbated by mass movements of refugees in response to food shortages and military conflicts. In these situations Prosopis has potential at least as a famine food, if not as a regular source of nutrition.

\section{Developing Prosopis as a human food in Kenya}

\section{Village-level trials}

In 2005, a project was launched in Kenya to develop incomegenerating activities using Prosopis. This project is working with villages in the Baringo District, which was selected because of the problem with invasive Prosopis, its dry bushland ecology and low agricultural potential, high levels of poverty, good communication facilities, and proximity to urban markets. $P$. juliflora was introduced to the area in 1982 and has spread considerably.

The first phase of the project was a workshop in Marigat village in February 2006. The aim of the workshop was to 
demonstrate and discuss Prosopis management and utilisation methods including its use as human food. The workshop ran over four days with twenty-six trainees and a further ten participants including village chiefs, district officials and farmer field school facilitators.

In Baringo District, the common types of flour used are maize, wheat and occasionally millet. Wheat flour is used for chapattis, pancakes, mandazi and cakes, and maize flour for the traditional ugali and uji. For mandazi, it was noted, a proportion of wheat flour can be substituted with maize flour, being cheaper, to reduce the cost with no real effect on taste. This was taken as an example of how P. juliflora flour could be used as a low-cost and nutritious substitute for up to a quarter of the flour in traditional recipes.

A tractor-powered hammer mill was used to mill whole pods, including seeds, into coarse flour. This was milled again in a local common roller mill ('pasha') for finer flour, but was still considered unsuitable and was passed through a still finer sieve. Flour from whole machine-milled pods that include seeds was preferred in terms of taste to that from pestle and mortar ground pods with seeds and capsules removed. Including seeds will increase the protein content and reduce the bitterness. Pods from $P$. pallida are known to be sweeter, but are relatively rare in Kenya.

After demonstration by a trainer using a mixture of wheat flour with $20 \%$ finely sieved Prosopis flour, the participants made chapattis at different mix ratios, pancakes, mandazi, ugali, uji and cake, and were proactive in developing new recipes, which are now available as a booklet. All of the food was cooked on traditional stoves using Prosopis charcoal. Taste tests and feedback on the different recipes indicated that all of the food made with 20\% Prosopis flour had a pleasant taste, whereas ugali made with $40 \%$ flour was not liked. Outreach strategies to spread the knowledge further are to include cookery demonstrations, samples and photos at public functions, and church and women's groups, and promotion of the recipes in the media and in a local hotel.

\section{Analysis of food quality and safety}

Clearly, if Prosopis is to be adopted as a human food in Kenya as is already the case in South America, then it will be necessary to confirm the nutritional value of the product and to test it for microbial contamination, mycotoxins and antinutritional factors. A sample of flour from Kenya was tested for aflatoxins and Ochratoxin A by Leatherhead Food International, Leatherhead, UK. The results in Table 6 indicate the presencce of aflatoxins and Ochratoxin A in the Prosopis flour. The levels of total aflatoxin and Aflatoxin B1 exceed the stringent EU maximum levels for cereals of 5 and $3 \mu \mathrm{g} \cdot \mathrm{kg}^{-1}$, respectively, but not the maximum levels adopted in the USA $\left(10 \mu \mathrm{g} \cdot \mathrm{kg}^{-1}\right)$, Brazil $\left(20 \mu \mathrm{g} \cdot \mathrm{kg}^{-1}\right)$ or India $\left(30 \mu \mathrm{g} \cdot \mathrm{kg}^{-1}\right)(\mathrm{FAO}, 2004)$. The Ochratoxin A level in Prosopis flour exceeded the maximum level of $5 \mu \mathrm{g} \cdot \mathrm{kg}^{-1}$ that has been proposed as an international standard by CODEX for Ochratoxin A in wheat, barley, rye and their derived products (USFDA, 2003), though this standard was opposed by some countries such as India who argued for a maximum level of $20 \mu \mathrm{g} \cdot \mathrm{kg}^{-1}$.

However, only one Kenyan Prosopis flour sample has been analysed so far and this had been produced from pods harvested in the wild and stored for several months. Levels of Ochratoxin A far higher than the levels shown in Table 6 are occasionally found in samples, including in European grain samples, when harvest, drying and storage conditions favour fungal growth and toxin production (Jørgensen et al., 1996; Elmholt

\begin{tabular}{|l|c|}
\hline \multicolumn{2}{|c|}{$\begin{array}{c}\text { TABLE } 6 \\
\text { Analysis of Prosopis } \text { juliflora flour } \\
\text { produced in Kenya }\end{array}$} \\
\hline Analysis & $\begin{array}{c}\text { Level } \\
\text { detected }\left(\boldsymbol{\mu g} \cdot \mathbf{k g}^{-1}\right)\end{array}$ \\
\hline Ochratoxin A & 38.0 \\
\hline Total aflatoxin & 5.8 \\
\hline Aflatoxin B1 & 4.7 \\
\hline "Flour produced from whole pods harvested \\
from wild trees and milled into flour
\end{tabular}

and Rasmussen, 2005). Similarly, significant levels of aflatoxin in common food products have been routinely reported in West Africa (Bankole and Adebanjo, 2003) and East Africa (Kaaya and Warren, 2005). In Uganda $29.6 \%$ of common food samples analysed tested positive for aflatoxin and approximately 12\% exceeded $100 \mathrm{ppm}$ total aflatoxin (Kaaya and Warren, 2005). Nevertheless, the results in Table 6 are of sufficient concern to warrant further study to determine toxin levels in freshly harvested pods, and in pods and flour after various periods of storage, and to develop appropriate harvesting and storage methods to minimise risk to human health. Among steps that may be necessary are early harvest, thorough drying and control of moisture levels during storage, discarding infested seeds, control of insect infestation and avoidance of carry over of inoculum in storage facilities.

Some indications of appropriate methods can be found in the traditional and improved storage and handling methods used in South America. Traditional pod stores in North America tended to consist of large baskets made from natural fibres, with a rain-proof roof, raised off the ground to prevent predation and to keep the pods dry (Felger, 1977). In Brazil, standard agricultural barns used for storing other dried animal feeds or special rooms with wooden floors and walls are used (e.g. Da Silva, 1996). In Peru, rustic closed rooms were used, made from mud bricks. These have largely been replaced with built block buildings (Grados and Cruz, 1996). Special storage units for $P$. pallida pods are built, $5 \times 5 \times 4 \mathrm{~m}$ high, which are capable of storing $40 \mathrm{t}$ of pods (Díaz Celis, 1995). In India, layers of dry pods are laid down alternately with layers of sand. This is said to increase storage time to three years. Periodic checking of the pods in the store is recommended to assess any damage due to fungal infections, high moisture or pests. Removal of infected pods should be carried out immediately. In Peru, however, once a pod store is filled, it is sealed with clay and opened only when the entire batch is to be sold.

\section{Further work}

To further disseminate the findings of the study, women from Baringo District ran a Prosopis cookery demonstration day at KEFRI in Nairobi. Plans are in progress to introduce the idea to other drought-affected areas of Kenya. Further work is required on:

- Milling, capacity for crushing the seeds, and accessibility and cost to pod collectors

- Pod collection methods, drying time and methods and storage for preserving flour quality and pest control

- Different recipes and preparation methods for flour products

- Nutritional composition of the flour, and different ratios of Prosopis to other flours

- The potential for local production of other food products from Prosopis pods. 
The potential for transferring this experience to other countries, nourishing rural people while controlling an invasive weed, appears enormous.

\section{References}

ANON. (1943) Nutritive values of Prosopis juliflora pods and some grasses. Indian For. 69 483-585.

ANTTILA LS, ALAKOSKI-JOHANSSON GM and JOHANSSON SG (1993) Browse preference of orma livestock and chemical composition of Prosopis juliflora and nine indigenous woody species in Bura, eastern Kenya. East Afr. Agric. For. J. 58 83-90.

AZEVEDO ROCHA RG (1987) Algaroba na alimentação e farmacopeia do homem rural Norte-Riograndense. Rev. Assoc. Brasileira de Algaroba (Mossoró) 1 67-96.

BAIÃO VB, GOMES JC, SANT'ANNA R and CRUZ R (1987) Chemical characteristics of mesquite beans (Prosopis juliflora) and amino acid composition of concentrate and a protein isolate. Arq. Biol. Technol. 30 275-286.

BANKOLE SA and ADEBANJO A (2003) Mycotoxins in food in West Africa: current situation and possibilities of controlling it. Afr. $J$. Biotech. 2 254-263.

BECKER R and GROSJEAN O-KK (1980) A compositional study of pods of two varieties of mesquite (Prosopis glandulosa, P. velutina). J. Agric. Food Chem. 28 22-25.

BOYD ML and COTTY PJ (2001) Aspergillus flavus and aflatoxin contamination of leguminous trees of the Sonoran Desert in Arizona. Phytopathol. 91 913-919.

BRAVO L, GRADOS N and SAURA-CALIXTO F (1994) Composition and potential uses of mesquite pods (Prosopis pallida $\mathrm{L}$ ) - comparison with carob pods (Ceratonia siliqua L). J. Sci. Food Agric. 65 303-306.

BURKART A (1976) A monograph of the genus Prosopis (Leguminosae subfam. Mimosoideae). (Part 1 and 2). Catalogue of the recognized species of Prosopis. J. Arnold Arbor. Harv. Univ. 57 219-249 and 450-525.

CHOGE SK, NGUNJIRI FD, KURIA MW, BASAKA EA and MUTHONDEKI JK (2002) Status and Impact of Prosopis in Kenya. Unpublished Technical Report. Kenya Forestry Research Institute and Forest Department, Nairobi, Kenya.

CRUZ G (1986) Obtención de Harina de Algarroba y Posibilidades de Usarla en Productos para la Alimentación Humana. Unpublished Eng. Thesis, Universidad de Piura, Peru.

CRUZ G (1990) Chemical Changes in Sugars and Amino Acids during the Roasting of Prosopis Pulp. Unpublished Report of a Research Stage at the ETH Zurich, Switzerland.

CRUZ G (1999) Production and Characterization and Uses of Prosopis Seed Galactomannan. Unpublished Ph.D. Thesis, ETH No. 13153, Zurich, Switzerland.

CRUZ G, DEL RE B and AMADO R (1987) Contribución al Estudio de la Composición Química de los Frutos Maduros del Algarrobo. In: Abstracts of III Jornadas Peruanas de Fitoquímica 122. Soc. Química del Peru, Lima, Peru.

DA SILVA JI (1996) Prosopis juliflora as an alternative source of food in the world's semiarid areas. In: Felker P and Moss J (eds.) Prosopis: Semiarid Fuelwood and Forage Tree; Building Consensus for the Disenfranchised. Center for Semi-Arid Forest Resources, Kingsville, Texas, USA 3.19-3.24.

DEL VALLE FR, MARCO E, BECKER R and SAUNDERS RM (1987) Development and evaluation of a procedure to produce mesquite (Prosopis spp.) pod protein-concentrate. J. Food Process. Preserv. 11 237-246.

DÍAZ CELIS A (1995) Los Algarrobos. Concytec, Lima, Peru.

ELMHOLT S and RASMUSSEN PH (2005) Penicillium verrucosum occurrence and Ochratoxin A contents in organically cultivated grain with special reference to ancient wheat types and drying practice. Mycopathol. 159 421-432.

FAO (2004) Aflatoxin Contamination in Foods and Feeds in the Philippines. Document 13. FAO/WHO Regional Conference on Food Safety for Asia and Pacific Seremban, Malaysia, 24-27 May. [Online]. Available at: <http://www.fao.org/DOCREP/MEET-
ING/006/AD729E/AD729E00.htm> (Accessed on 14/07/06).

FELGER RS (1977) Mesquite in Indian cultures of southwestern North America. In: Simpson BB (ed.) Mesquite: Its Biology in Two Desert Ecosystems. Dowden, Hutchinson and Ross, Stroudsburg, Pennsylvania, USA 150-176.

FELKER P (1979) Mesquite: An all-purpose leguminous arid land tree. In: Ritchie GA (ed.) New Agricultural Crops. AAAS Symposium 38 89-125.

FIGUEIREDO AA (1975) Lebensmittelchemisch Relevanter Inhaltsstoff der Schoten def Algarobeira (Prosopis juliflora DC). Unpublished Ph.D. Thesis, University of Würzburg, Germany.

GALERA FM, TREVISSON M and BRUNO SA (1992) Prosopis in Argentina: initial results on cultivation in greenhouses and orchards, and pod quality for food or feed of five native Prosopis species of Córdoba Province. In: Dutton RW (ed.) Prosopis Species: Aspects of their Value, Research and Development. CORD, University of Durham, Durham, UK 145-156.

GOHL B (1981) Tropical Feeds. FAO Animal Production and Health Series 12 FAO, Rome, Italy.

GRADOS N and CRUZ G (1996) New approaches to industrialization of algarrobo (Prosopis pallida) pods in Peru. In: Felker P and Moss J (eds.) Prosopis: Semiarid Fuelwood and Forage Tree; Building Consensus for the Disenfranchised. Center for Semi-Arid Forest Resources, Kingsville, Texas, USA 3.25-3.42.

JIMÉNEZ B and VERGARA AN (1977) Estudio sobre la Composición Química y Posibilidades de Industrializacion de la Algarroba. Unpublished Eng. Thesis, Universidad de Piura, Peru.

JOHANSSON SG (1990) Controlling and Containing the Spreading of Prosopis spp. at Bura. An Outline of Options and Required Actions. Research Component in Bura Fuelwood Project. Unpublished Working Paper 47.

JØRGENSEN K, RASMUSSEN G, and THORUP I (1996) Ochratoxin A in Danish cereals 1986-1992 and daily intake by the Danish population. Food Addit. Contam. 13 95-104.

KAAYA NA and WARREN HL (2005) A review of past and present research on aflatoxin in Uganda. Afr. J. Food Agric. Nut. Develop. (On-line Version), 5. Available at http://www.ajfand.net/Vol5no1. $\mathrm{htm}>$ (Accessed on 14/07/06).

LIMA PCF (1994) Comportamento Silvicultural de Especies de Prosopis, em Petrolina-PE, Região Semi-Arida Brasileira. Unpublished Ph.D. Thesis, Universidade Federal do Parana, Curitiba, Brazil.

MARANGONI A and ALLI I (1988) Composition and properties of seeds and pods of the tree legume Prosopis juliflora (DC). J. Sci. Food Agric. 44 99-110.

MEYER D, BECKER R and NEUKOM H (1982) Milling and separation of Prosopis pod components and their application in food products. In: Parker HW (ed.). Mesquite Utilization. Texas Tech University, Lubbock, Texas, USA L1-L12.

MONTE-NEGREIROS A, CARVALHO M, FILHO JX, BLANCOLABRA A, SHREWRY PR and RICHARDSON M (1991) The complete sequence of the major kunitz trypsin inhibitor from the seeds of Prosopis juliflora. Phytochem. 30 2829-2833.

OCHOA J (1996) A review of the social and economic opportunities for Prosopis (algarrobo) in Argentina. In: Felker P and Moss J (eds.) Prosopis: Semiarid Fuelwood and Forage Tree; Building Consensus for the Disenfranchised. Center for Semi-Arid Forest Resources, Kingsville, Texas, USA 5.19-5.34.

ODUOL PA, FELKER P, MCKINLEY CR and MEIER CE (1986) Variation among selected Prosopis families for pod sugar and pod protein contents. For. Ecol. Manage. 16 423-431.

ORTEGA-NIEBLAS M, VAZQUEZ-MORENO L and ROBLES-BURGUEÑO MR (1996) Protein-quality and antinutritional factors of wild legume seeds from the Sonoran desert. J. Agric. Food Chem. 44 3130-3132.

OTSAMO A and MAUA JO (1993) Observations on pod production of planted Prosopis juliflora. East Afr. Agric. For. J. 58 111-114.

PAK N, ARAYA H, VILLALON R and TAGLE MA (1977) Analytical study of tamarugo (Prosopis tamarugo) an autochthonous Chilean feed. J. Sci. Food Agric. 28 59-62.

PASIECZNIK N (2002) Prosopis juliflora (Vilayati babul) in the Drylands of India: Develop this Valuable Resource, Don't Eradicate It. HDRA, Coventry, UK. 
PASIECZNIK NM, FELKER P, HARRIS PJC, HARSH LW, CRUZ G, TEWARI JC, CADORET K and MALDONADO LJ (2001) The Prosopis juliflora - Prosopis pallida Complex: A Monograph. HDRA, Coventry, UK

RUIZ W (1997) Enriquecimiento Proteico de la Pulpa de Algarroba Mediante Multiplicación de Levaduras. Unpublished Eng. Thesis, Universidad de Piura, Peru.

SÁENZ G, SERRA JA and ESCRICHE I (1987) Composición química de la algarroba peruana (Prosopis sp.). In: Fito P and Mulet A (eds.) Proc. $2^{\text {nd }}$ Int. Carob Symp. Generalitat Valenciana, Valencia, Spain. 419-427.

SALAZAR I (1993) Cuantificación de taninos en cada una de las fracciones del fruto del algarrobo. Unpublished Eng. Thesis, Universidad de Piura, Peru.

SAUNDERS RM, BECKER R, MEYER D, DEL VALLE FR, MARCO E and TORRES ME (1986) Identification of commercial milling techniques to produce high sugar, high-fiber, high protein, and high galactomannan gum fractions from Prosopis pods. For. Ecol. Manage. 16 169-180.

SAURA F, CLAVIJO J and ABIA R (1991) Características químicas del endocarpio del fruto del algarrobo piurano. Bol. Soc. Quim. Peru 57 245-250.
SIMPSON BB (1977) Mesquite, Its Biology in Two Desert Shrub Ecosystems. Dowden, Hutchinson and Ross, Stroudsburg, Pennsylvania, USA.

TALPADA PM (1985) Study on Prosopis juliflora Pods and Utilization as Cattle Feed by Lactating Cows. Unpublished Ph.D. Thesis, Gujarat Agricultural University, Anand, India.

TOUZEAU J (1973) Les Arbres Fouragers de la Zone Sahélienne de l'Afrique Volume 75. Ecole Nationale Vétérinaire de Toulouse, Toulouse, France.

USFDA (2003) Mycotoxins in domestic foods. Chapter 7. In: Mol. Biol. and Natural Toxins. [Online]. Available at: $<$ http://www.cfsan.fda. gov/ comm/cp07001.html > (Accessed on 14/07/06).

ZIMMERMANN HG (1991) Biological control of mesquite, Prosopis spp (Fabaceae) in South Africa. Agric. Ecosyst. Environ. 37 175186.

ZOLFAGHARI R and HARDEN M (1982) Nutritional value of mesquite beans (Prosopis glandulosa). In: Parker HW (ed.) Mesquite Utilization. Texas Tech University, Lubbock, USA K1-K16. 